\title{
Evolution of the predictive criteria for the tropical fruit tree nutritional status
}

\section{Evolução dos critérios de predição do estado nutricional de frutíferas tropicais}

\author{
Danilo Eduardo ROZANE'; Léon Etienne PARENT²; William NATALE ${ }^{3}$ \\ 1 (Corresponding author) Agr. Engineer, Dr. Professor, Universidade Estadual Paulista "Júlio de Mesquita Filho" - Unesp \\ Câmpus de Registro; Rua: Nelson Brihi Badur, 430, Vila Tupy - 11900-000, Registro-SP. E-mail: \\ danilorozane@registro.unesp.br \\ ${ }^{2}$ Agronomist, Ph.D., Professor. Departement of Soils and Agrifood Engineering, Paul-Comtois bldg.,Université Laval, \\ Québec, G1K 7P4, Canada. E-mail: leon-etienne.parent@ fsaa.ulaval.ca \\ ${ }^{3}$ Agr. Engineer, Invited Professor, Université Laval, Québec, Canada, E-mail: william.natale@fsaa.ulaval.ca
}

Recebido em: 23-03-2015; Aceito em: 15-08-2015

\begin{abstract}
The diagnosis of plant nutritional status that aims to balance essential elements in the plant is of utmost importance for sustainable agriculture. Nutritional diagnosis is a technique that has been implemented to maximize the economic return from fertilization and minimize losses to the environment. A balance can be defined as a relationship between components interacting in plant tissue, where some nutrients may be present in excess, deficiency or sufficiency. Diagnostic methods have been evolving constantly, allowing to interpret nutrient levels in isolation to more complex methods accounting for nutrient interactions.
\end{abstract}

Additional keywords: Plant nutrition, nutrient composition, nutrient interaction, compositional nutrient diagnosis.

\section{Resumo}

A diagnose nutricional, ou seja, o conhecimento sobre o equilíbrio entre os elementos essenciais no tecido vegetal, é uma técnica empregada para elevar ao máximo o retorno econômico nas explorações agrícolas, preservando de forma racional o ambiente. O equilíbrio pode ser comparado a uma balança de pratos, na qual os nutrientes podem estar presentes em excesso, deficientes ou em teores adequados (informação relativa), considerando-se o teor dos demais componentes. A predição do diagnóstico do estado nutricional das plantas é de extrema importância para a agricultura durável, cujos métodos têm evoluído constantemente, permitindo uma interpretação imparcial dos teores dos nutrientes e de suas interações.

Palavras-chave adicionais: Nutrição de plantas, composição nutricional, interação de nutrientes, CND.

\section{Introduction}

Agriculture is the rational exploitation of the photosynthetic capacity of plants. Biotic and abiotic factors that affect photosynthesis may be uncontrollable (light, temperature, etc.), partly controllable (water, soil, etc.) or controllable to large extent (plant species, cultivation and crop management). A major objective of studying plant mineral nutrition is to increase productivity with quality through fertilization efficient management. Despite broad scientific and technical recognition of the importance of liming and fertilization in tropical areas, research on the effects of liming and fertilization on the development and nutritional status of fruit trees is relatively scarce. For a long time, some fruit trees, especially those native to the tropical regions such as guava and starfruit, were considered hardy plants growing well regardless of soil and climate conditions. However, one cannot imagine that soil nutrients can be mined indefinitely without maintenance. Due to the perennial nature of fruit trees, long-term experiments are necessary but expensive, limiting the investment in such research. Here we review the crop mineral nutrition of fruit trees with emphasis on diagnosis, liming and fertilization.

Fruit trees are perennial species that do not respond to liming and fertilization the same way as annual crops because: (1) perennial plant roots exploit a large volume of soil that expands with plant age, and the nutritional reserves of deeper soil layers is little documented; (2) the perennial plant as a whole (roots, branches, trunk and leaves) has considerable internal nutrient reserves. As a result, the effects of nutritional disorders and nutrient corrections appear slowly in trees; (3) pruning is necessary to control leaf access to light and to prevent alternate fruit bearing. By restricting vegetative growth, the results of improved plant nutrition do not show up immediately, and (4) liming and fertilization support the vegetative and fruiting plant parts. Applied nutrients feed the pending production and new fruit-bearing branches and accumulate in roots and shoots for the next fruiting events.

Liming practice increases nutrients use efficiency, improving the cost/ benefit ratio through 
increased productivity. Because fruit plants exploit practically the same volume of soil during long periods, the acid root environment of tropical soils deserves the utmost attention. On the other hand, crop yield depends on the nutrient balance, which is characterized by well-defined ratios between elements as illustrated in Figure 1.

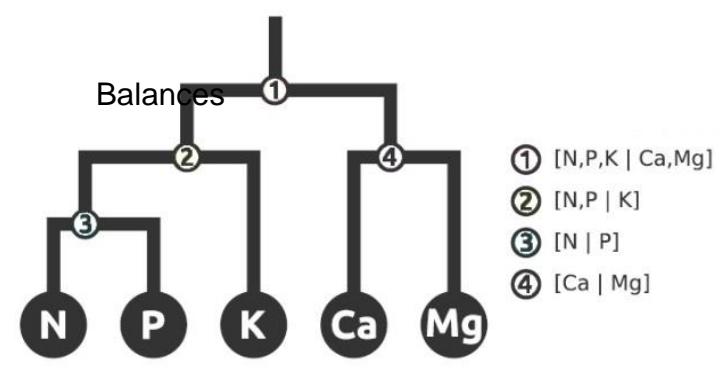

Figure 1 - Hierarchical balance points representing nutrient interrelationships (Parent et al., 2013a).

Therefore, nutrient additions taken in isolation is not enough to achieve high yield because nutrients interact with each other. Figure 1 shows that for five interacting nutrients $(D=5)$, there are four (D-1) interpretable independent combinations of nutrients called balances, a priori designed by the researcher. Crop productivity is highest where all production factors in buckets are close to their optimum combinations indicated at fulcrum.

Besides soil analysis, it is advantageous for perennial crops to conduct foliar analysis because tree roots explores the deeper than the arable layer and trees acquire certain nutrition stability at physiological maturity (Marschner, 1995). Foliar diagnosis at flowering or early fruit development in fruit trees allows to adjust fertilization programs in time to avoid productivity losses at the end of the cropping season.

\section{Nutritional Diagnosis of Fruit Trees}

Several factors are responsible for low crop yields in the tropics, especially liming and crops fertilization mismanagement in response to the limited capacity of soils to meet plant nutritional requirements. Proper nutrition not only determines productivity, but also affects fruit quality (appearance, color, taste, size, aroma, post-harvest storage and tolerance to pests and diseases). Thus, accurate diagnosis of the plant nutritional status a key element to assist decision makers in the highly competitive fruit production market. Proper nutrition management allows the rational utilization of inputs such as lime and fertilizers, enhancing farm profitability at minimum environmental risk. However, making use of these tools requires technical expertise and understanding of all factors involved in crop production.

\section{Tissue analysis}

Diagnostic standards are commonly established using crop surveys and field experiments relating crop performance to soil and plant tissue analyses. Soil chemical analysis ignores other aspects that may limit nutrients absorption such as aeration, temperature, competition between nutrients, and plant nutrient demand. Moreover, it is economically not feasible to collect soil samples representing the soil volume explored by the roots. Malavolta (2006) explained that a soil sample taken to the laboratory has static characteristics not accounting for crop development in relation to climate, topography, management, etc. Leaf analysis is thus a valuable tool to diagnose crops nutrition as complementary tool in fertilizer recommendation. Leaf analysis provides an integrative measure of nutrient acquisition and would thus be more reliable than soil analysis as indicator of nutrient availability in the soil (Epstein \& Bloom, 2006). Where nutrient deficiency is severe, symptoms begin to appear, but production losses have already occurred. Leaf analysis makes it possible to identify nutrient deficiencies causing similar visual symptoms or before visual symptoms appear on the leaf.

There is no full assurance for adequate nutrients supply resulting from input application for optimum crop performance because myriads of growth-limiting factors operate in isolation or in combination during the growing season (Bataglia, 2005). Nutrients present and assimilated in sufficient amounts in growth hotspots are decisive factors for plant development because high crop productivity requires regular and balanced nutrient supply. Extreme imbalances in the supply of essential elements cause high metabolic stresses that affect crop production and quality.

\section{Diagnostic standards}

Chemical plant analysis for diagnostic purposes is based on the premise that there are causal relationships between plant growth rate and nutrient content in the plant dry matter. Leaves are considered to be the center of physiological activities that are reflected by the crop nutritional status. Nutrient supply influences leaf element concentrations. 
However, nutrients sustain high crop productivity within certain critical concentration ranges. Surveys of the plant nutrient status has been widely used to interpret the results of plant tissue analysis to improve crop yields with proper liming and fertilization. Several factors are responsible for variations in plants nutrient concentrations, especially soil, climate and plant age and genetic makeup. Surveys on crop nutritional status assists allows correlating soil and plant analyses and comparing them with the critical levels found in highly productive and high-quality commercial crops as standards (Malavolta, 2006). The sampling technique must be standardized for consistent diagnosis. In order to calibrate nutrient applications and secure maximum economic return on the long run, nutrition studies in fruit crops must be conducted in long-term experiments (Natale et al., 2011). Any shortage in soil nutrient supply will be reflected in different parts of the plant, but the freshly mature leaves are commonly used for such assessment.

There are several nutritional status assessment techniques (Malavolta, 2006) such as: a) visual diagnosis; b) leaf diagnosis; c) biochemical tests; d) infiltration techniques; e) indirect chlorophyll measurement; f) bio-assessment; $g$ ) and analysis of other organs. Visual diagnosis is the most common among researchers, technicians and extension advisers: it is a quick way to identify nutrient deficiency or excess but economic damage has already occurred: there is a sequence of events beginning at molecular level and progressing until changes are visible in the plant tissue. Leaf analysis techniques have thus been develop to determine to what extent of a particular nutrient limits plant growth (Mourão Filho, 2000).

\section{History and Evolution of Diagnostic Methods}

The search for efficient diagnostic methods to assess plants nutritional status has been the subject of much research since the mid- $20^{\text {th }}$ century. The idea of using leaf nutrient concentrations as diagnostic criteria in plant nutrition was pioneered in Montpellier, France, by Lagatu \& Maume (1934 a, b) who also illustrated inter-relationships between $\mathrm{N}, \mathrm{P}$ and $\mathrm{K}$ in potato and grape using a ternary diagram (Figure 2). The balance between proportions of $\mathrm{N}, \mathrm{P}$ and $\mathrm{K}$ in the leaf NPK sub-composition indicates physiologically related nutrients and support the multivariate character of plant tissue components. The percentage of each nutrient adds up to $100 \%$, the NPK subcomposition of the dry leaf. Each element is located at the vertices of the triangle, whose parallels converge to show the balance point. This geometric representation of nutrient interactions, inspired by the ternary diagrams designed in sedimentology to represent the sand-silt-clay simplex at the beginning of the $20^{\text {th }}$ century, found a numerical solution much later with the development of compositional data analysis (Aitchison, 1986; Egozcue et al., 2003).

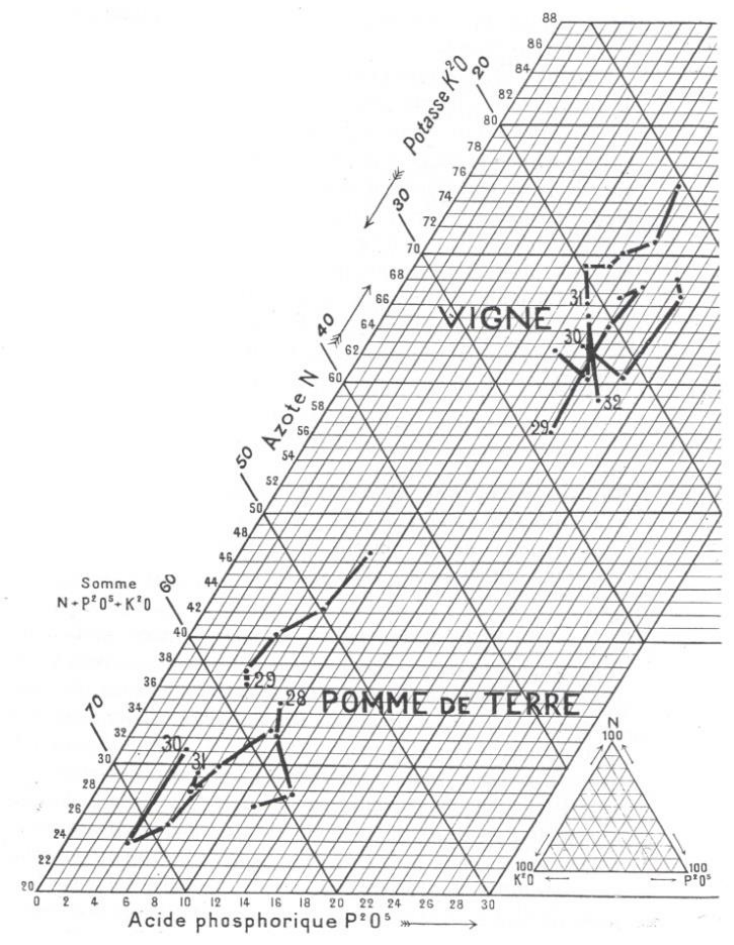

Figure 2 - Diagram relating $\mathrm{N}, \mathrm{P}_{2} \mathrm{O}_{5}$ and $\mathrm{K}_{2} \mathrm{O}$ in potato (Pomme de terre) and grape (Vigne) leaves in response to fertilizer applications (original figure from Lagatu \& Maume, $1934 \mathrm{a}, \mathrm{b}$ ). 
The results of plant tissue analysis can be interpreted by univariate methods such as critical content (CT) and sufficiency range (SF), bivariate methods such as the diagnosis and recommendation integrated system (DRIS), and multivariate methods such as the compositional nutrient diagnosis (CND).

\section{Critical concentration levels}

Critical concentration or critical content (CT) concept was introduced by Ulrich \& Hills (1967) using the well-known graphic representation shown in Figure 3. In the regions of the graph indicated as "deficiency zone" (levels below the transition zone), the plant tends to increase its production in response to nutrient supply.

The addition of the growth-limiting nutrient results in a growth/production curve increasing with nutrient leaf levels. The point on the curve at which plant growth is reduced by $10 \%$ is considered ass the critical nutrient concentration. The transition zone relates nutrient deficiency and sufficiency levels (Ulrich \& Hills, 1967). Production has an upper limit implying luxury consumption (Figure 4) above the adequate zone (Figure 3). Nutrient luxury consumption by crops is economically unsatisfactory because the crop does not converting nutrients into marketable products.

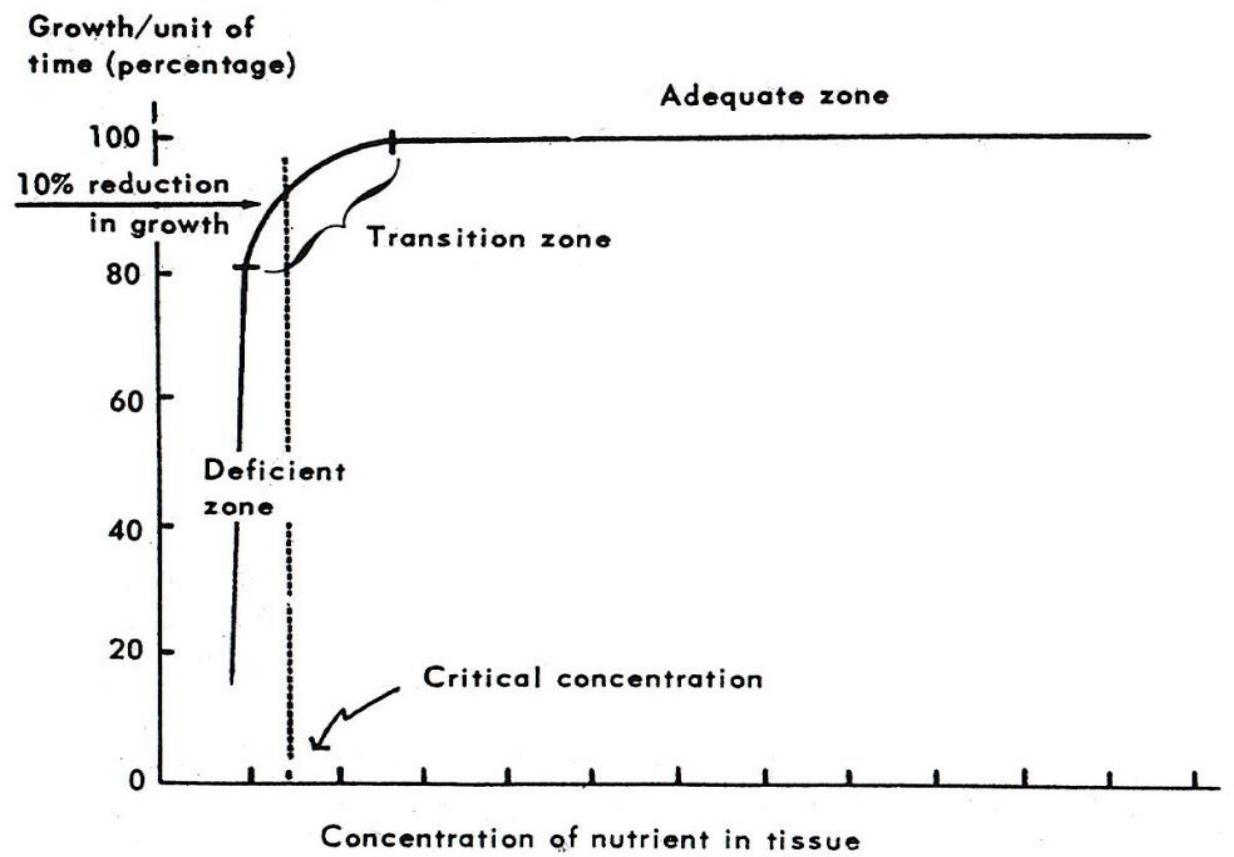

Figure 3 - Representation of the critical nutrient concentration in plant tissues (Ulrich \& Hills, 1967).

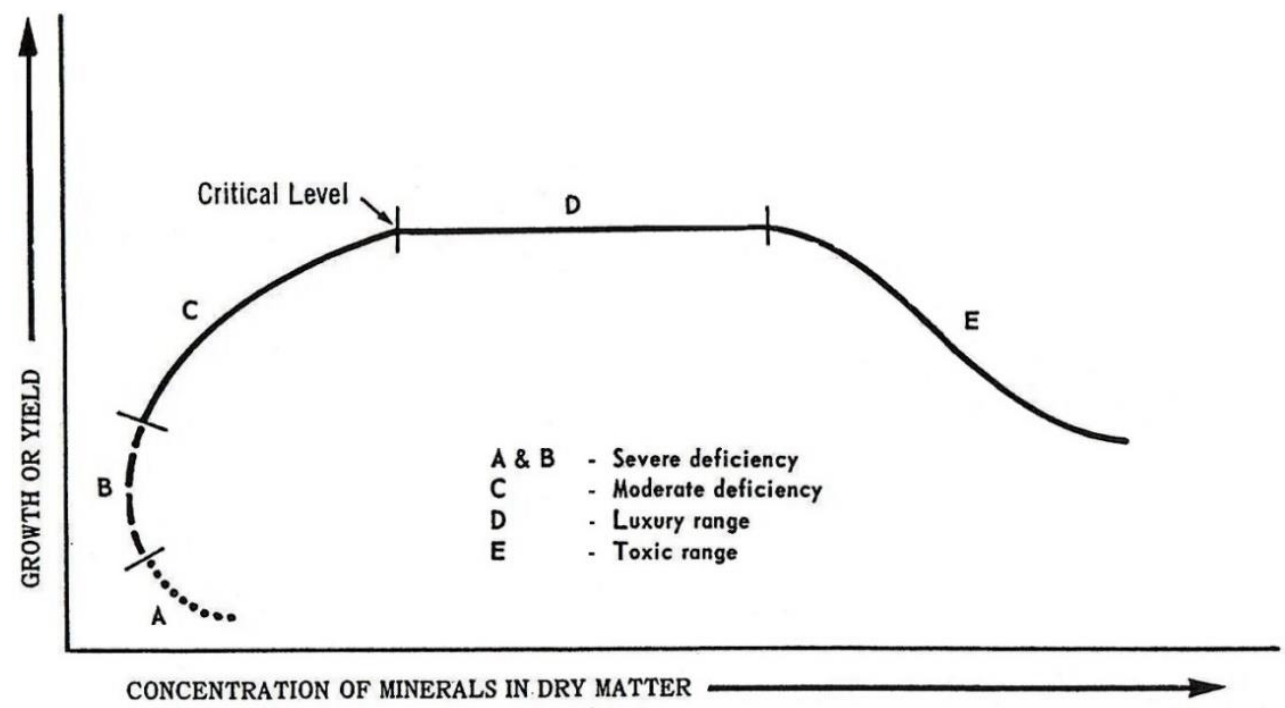

Figure 4 - Relationship between tissue mineral composition ( $\mathrm{x}$ axis) and growth/yield (y axis). Original figure translated and adapted from Smith (1962) and Prevot \& Ollagnier, (1957). 
The sufficiency range method uses nutrient foliar intervals to indicate the plant nutritional status. The classical critical concentration curve shown in Figure 4 is based on studies by Smith (1962) and Prevot \& Ollagnier (1957). In Figures 3 and 4, the terms zone and level, or range are being used, but confidence intervals not defined explicitly. The sufficiency range method illustrated in Figure 4 is based on the relationship between nutrient concentration and production over a large range of nutrient concentrations.

Results of tissue analysis are interpreted by comparison with reference values. Such values can be established in field calibration experiments where genetic and environmental characteristics and their interactions with nutrients are controlled (Bhargava \& Chadha, 1988). However, crop diagnosis for situations beyond the experimental conditions makes the process very restrictive for large-scale use in agriculture. In addition, reference values are updated regularly because new genetic material and management or cultivation techniques are being introduced and environmental condition vary. Updating requires new calibration trials which are expensive to conduct in the medium to long run. Alternatively, surveys of commercial stands provide data from a broad variation of environmental conditions to obtain the reference values with DRIS and CND. The DRIS (Beaufils, 1973) assumes that dual nutrient ratios are representative of nutrient balances while CND relates all nutrient components between them to define balance (Parent \& Dafir, 1992; Parent, 2011). The DRIS and CND have the advantage over CT and simple dual ratios to order the nutrient according to their yield limitation from the most limiting nutrient to the one present in most excessive amount (Bataglia et al., 1996; Parent \& Dafir, 1992).

\section{DRIS}

Compared to CT, DRIS is a computation procedure that could reduce dependency from local conditions and account for dual nutrient interactions and nutrient dilution. The interpretation of DRIS is based on nutrient indices computed from DRIS functions. Positive DRIS indices indicate nutrient excess and negative indicate relative nutrient deficiency; DRIS indices equal or close to zero indicate nutrient balance.

In Brazil, studies on DRIS reported on all possible ratios between nutrients for index calculations (Bataglia \& Santos, 1990; Leite, 1993). However, some authors recommended including only ratios showing significant differences between the low-yielding and the reference subpopulations (Beaufils, 1973; Elwali \& Gascho, 1984). Others recommend using 'log-transformed' ratios to correct deviations in normal distribution between direct and reverse forms of expression of the same ratio (Holland, 1966; Beverly, 1987, 1993).
The definition of reference DRIS population is large. Beaufils (1973) and Walworth \& Sumner (1987) did not propose any specific criteria to partition high and low productivity populations. Letzsch \& Sumner (1984) recommended that high-yielding specimens should include at least $10 \%$ of the database. Hoogerheide (2005) suggested relying on the best relationship between nutrient balance index (NBI) and productivity. Silva et al. (2005) suggested mean \pm 0.5 standard deviation to define the high-yielding population. Malavolta (2006) recommended $80 \%$ of maximum productivity. Sierra et al. (2010) suggested the population mean. As a result, the reference population definition is still largely subjective. In addition, the DRIS computation methods changed over time empirically, seeking for adjustment to nutrient dilution and nutrient separation to facilitate interpreting the deficiency-excess order. First intended to diagnose several factors impacting on agricultural production, DRIS is currently used to assess crops nutrient status. DRIS appeared to be advantageous over CT and SR because nutrient ratios allow considering all possible interactions between nutrients. Holland (1966) noted that, as the number of nutrients to be examined simultaneously increases, diagnosis consistency also increases, until the interpretation method involves all elements: principal component analysis after logarithmic transformation, in order to make original variable functions linear, could thus improve leaf diagnosis compared to univariate or bivariate methods. However, nutrient concentrations and DRIS is not amenable to principal component analysis due to the special properties of compositional data (Aitchison, 1986). In addition, DRIS computations have never been validated by mathematicians and convey spurious correlations that obscure results in biology (Pearson, 1897; Tanner, 1949) and geosciences (Chayes, 1960). Spurious correlations occur where correlating ratios containing a common variable (e.g., $\mathrm{N} / \mathrm{P}$ and $\mathrm{P} / \mathrm{K})$. As a result of such spurious 'interrelationships', the addition of DRIS functions to DRIS indices is inflated.

\section{CND}

The DRIS technique proved to be geometrically unsuitable and thus replaced by compositional nutrients diagnosis (CND) (Parent \& Dafir, 1992). The CND expands to all nutrients the NPK ternary diagram of Lagatu \& Maume (1934a, b) using tools of compositional data analysis (Aichison, 1986; Egozcue et al., 2003; Egozcue \& PawlowskyGlahn, 2005). Aitchison (1986) was the first to show that compositional data convey relative information within a closed space and that multivariate analysis of compositional data is spoiled by redundancy, scale dependence and non-normal distribution. Indeed, any component can be computed by difference between the unit of measurement and the sum of other components (e.g., \%silt = 100\% - \%sand - \% clay), 
therefore there are $D-1$ degrees of freedom in a $D$ part composition (Aitchison \& Greenacre, 2002). On the other hand, tissues compositions are values relative to some scale (e.g. fresh or dry tissue) or unit (e.g., g kg-1 dry leaf mass): results and conclusions depend on the scale being used, hence leading to much confusion in the scientific literature. The problem of non-normal distribution shows up clearly after conducting linear statistical analyses when confidence intervals range beyond the compositional space (i.e. below 0 or above $100 \%$ ) and where the sum of components differ from $100 \%$.

The CND technique has been developed at Laval University, Canada, by Parent and his colleagues (Parent \& Dafir, 1992; Parent et al., 1994a, b; Parent et al., 1995; Parent \& Khiari, 2003; Parent et al., 2005) for several crops. In Brazil, some studies were carried out with CND in soybean (Urano et al. 2006; Urano et al., 2007), eucalyptus (Silva et al., 2004), guava (Rozane et al., 2012) and mango (Parent et al., 2013b). The original CND method used D log-centered ratios (c/r) or contrasts as recommended to avoid biases in compositional data analysis (Aitchison, 1986). The CND-clr adjusts a nutrient concentration to the geometric mean across components including the filling value between the unit of measurement and the sum of analytical results. The CND-clr shows that the ordinary log transformation suggested by Holland (1966) convey some bias because the difference $\ln \left(N_{1}\right)-\ln \left(N_{2}\right)$ is compositionally unbiased if and only if the geometric means across components are the same (Lovell et al., 2011), i.e. $g_{1}=g_{2}$ : indeed $\ln \left(N_{1} / g_{1}\right)-$ $\ln \left(N_{2} / g_{2}\right)$. The CND-clr thus generates a correction factor as a geometric mean, expanding DRIS from a two- to a multi-dimensional concept appropriate for the inherently multivariate character of compositional data. Another advantage of CND-c/r is the possibility to compute an unbiased imbalance index using the Mahalanobis Distance (Parent et al., 2009). Compared to DRIS that cannot evolve consistently, CND-clr can take advantage of all packages of multivariate data analyses after removing the filling value to avoid matrix singularity (Parent et al., 2009; Parent et al., 2013a, b).

Parent et al. (1995) observed $\mathrm{N}$ limitation in conifer seedlings using CND-clr more clearly compared to $\mathrm{N}$ concentration. Close correlations were found between DRIS and CND-clr indices in potato (Parent et al., 1994a) and carrot (Parent et al., 1994b) crops grown in Quebec, Canada. However, CND-clr required less computational effort. Diagnostic performance of CND-clr was $87.5 \%$ in potato (Parent et al., 1994a). Parent et al. (2005) diagnosed $\mathrm{N}$ in Christmas trees at 174 locations in Canada and concluded that CND-clr properly discriminated the $\mathrm{N} / \mathrm{P}$ ratio in the trees, $\mathrm{N}$ being the most deficient.

Egozcue et al. (2003) improved the clr approach of Aitchison (1986) by reducing the $\mathrm{D} c / r$ values to $\mathrm{D}-1$ isometric log ratios (ilr) between subsets of components without any information loss based on the principle of orthogonality. The ilr can be projected directly into the Euclidean space to facilitate computing multivariate distances. The ilr are directly amenable to principal component analysis and other modern computational tools. Parent (2011) and Parent et al. (2012) used ilr coordinates as meaningful contrasts between geometric means of nutrient subsets that are interpretable.

\section{Compositional Analysis and CND Application: Examples}

We conducted a fertilizer trial with $\mathrm{N}$ and $\mathrm{K}$, the nutrient most exported by guava trees. The design was in randomized blocks with $4 \mathrm{~N}$ and $4 \mathrm{~K}$ doses repeated thrice. The $\mathrm{N}$ doses were zero, 500 , 1000 and $2000 \mathrm{~g} \mathrm{~N} \mathrm{plant}^{-1}$ as urea, and the $\mathrm{K}$ doses were zero, 550, 1100 and $2200 \mathrm{~g} \mathrm{~K}_{2} \mathrm{O}$ plant $^{-1}$ as potassium chloride. There were five trees per plot and the three central trees were monitored. Leaf nutrient concentration, soil fertility and fruit production were determined during three consecutive cycles (Amorim et al., 2015). Balances were designed to improve the understanding of $\mathrm{N}$ and $\mathrm{K}$ fertilizer effects on the soil using the sequential binary partition in Table 1 used to compute ilr coordinates. There 11 components, hence 10 balances. The same procedure was followed for foliar analysis (Table 2). Further details on the calculation of formulas and indexes can be obtained in Parent (2011). The $\mathrm{N}$ fertilization acidified the soil due to urea transformation into nitrate. Fruit production increased with $\mathrm{N}$ (Figure 5). The $\mathrm{K}$ fertilization increased soil exchangeable $\mathrm{K}$ hence the [K | Ca, Mg] balance. Sampling period affected almost all ilr, both due to sampling season variation and phytosanitary treatment. Crop response was significant depending on the season (Table 3).

Guava trees produced significantly more fruits when the development cycle occurred during the fall/spring season, followed by the spring/fall and the winter/summer seasons (Table 3). Although soil and irrigation conditions were the same in the experimental orchard, seasonal variations influenced fruit yield due to variations in temperature, light, precipitation, etc. There were significant differences in total variance depending on production cycle (Figures 6 and 7).

We investigated whether the nutrient signature varied among cultivars in 170 commercial stands in northwestern São Paulo state: 93 'Palmer', 63 'Tommy' and 14 'Espada' cultivar. Orchards were located in the same region to minimize variations in environmental conditions and farming practices. After ilr transforming nutrient concentrations to avoid bias in multivariate analysis, we found genotype effect on nutrient signatures (Figure 8), suggesting that the nutrient balance standards should be elaborated by cultivar. Thus, for guava nutrient balances varied with climate conditions for guava (Figure 7) and cultivars (Figure 8) for mango. 
Nutrient interactions in plant nutrition studies make a constant challenge to the researcher. The diagnostic concept of nutrient balances based on CND-clr or CND-ilr performed more than the mere finding that the any given element taken in isolation can limit plant growth and yield. Multi-nutrient analysis allows studying interactions of interest by defining the high productivity population mathematically and avoiding distortions due to data redundancy, non-normal distribution, and subcompositional incoherence.

Table 1 - Chemical properties isometric log-ratio (IIr) of a 'Paluma' guava orchard soil.

\begin{tabular}{rrrrrrrrrrrrrrr}
\hline IIr & $\mathrm{P}$ & $\mathrm{S}$ & $\mathrm{K}$ & $\mathrm{Ca}$ & $\mathrm{Mg}$ & $\mathrm{H}+\mathrm{Al}$ & $\mathrm{B}$ & $\mathrm{Cu}$ & $\mathrm{Zn}$ & $\mathrm{Mn}$ & $\mathrm{Fe}$ & $\mathrm{r}$ & $\mathrm{s}$ & Balances \\
\hline & & \multicolumn{1}{c}{---} & Orthogonal components & sequential partition & --- & & & & & \\
1 & 1 & 1 & 1 & 1 & 1 & 1 & 1 & -1 & -1 & -1 & -1 & 7 & 4 & 1.595 \\
2 & 1 & 1 & 1 & 1 & 1 & 1 & -1 & 0 & 0 & 0 & 0 & 6 & 1 & 0.926 \\
3 & 1 & 1 & -1 & -1 & -1 & -1 & 0 & 0 & 0 & 0 & 0 & 2 & 4 & 1.155 \\
4 & 1 & -1 & 0 & 0 & 0 & 0 & 0 & 0 & 0 & 0 & 0 & 1 & 1 & 0.707 \\
5 & 0 & 0 & 1 & -1 & -1 & -1 & 0 & 0 & 0 & 0 & 0 & 1 & 3 & 0.866 \\
6 & 0 & 0 & 0 & 1 & 1 & -1 & 0 & 0 & 0 & 0 & 0 & 2 & 1 & 0.816 \\
7 & 0 & 0 & 0 & 1 & -1 & 0 & 0 & 0 & 0 & 0 & 0 & 1 & 1 & 0.707 \\
8 & 0 & 0 & 0 & 0 & 0 & 0 & 0 & 1 & 1 & -1 & -1 & 2 & 2 & 1.000 \\
9 & 0 & 0 & 0 & 0 & 0 & 0 & 0 & 1 & -1 & 0 & 0 & 1 & 1 & 0.707 \\
10 & 0 & 0 & 0 & 0 & 0 & 0 & 0 & 0 & 0 & 1 & -1 & 1 & 1 & 0.707 \\
\hline
\end{tabular}

$\mathrm{r}=$ number of positive signs; $\mathrm{s}=$ number of negative signs.

Table 2 - Isometric log-ratio (IIr) coordinates of the nutritional composition of 'Paluma' guava leaves.

\begin{tabular}{|c|c|c|c|c|c|c|c|c|c|c|c|c|c|c|}
\hline IIr & $\mathrm{N}$ & $\mathrm{P}$ & $\mathrm{S}$ & $\mathrm{K}$ & $\mathrm{Ca}$ & $\mathrm{Mg}$ & B & $\mathrm{Cu}$ & $\mathrm{Zn}$ & $\mathrm{Mn}$ & $\mathrm{Fe}$ & $\mathrm{r}$ & $\mathrm{s}$ & Balances \\
\hline \multicolumn{15}{|c|}{--- Orthogonal components sequential partition --- } \\
\hline 1 & 1 & 1 & 1 & 1 & 1 & 1 & 1 & -1 & -1 & -1 & -1 & 7 & 4 & 1.595 \\
\hline 2 & 1 & 1 & 1 & 1 & 1 & 1 & -1 & 0 & 0 & 0 & 0 & 6 & 1 & 0.926 \\
\hline 3 & 1 & 1 & 1 & -1 & -1 & -1 & 0 & 0 & 0 & 0 & 0 & 3 & 3 & 1.225 \\
\hline 4 & 1 & 1 & -1 & 0 & 0 & 0 & 0 & 0 & 0 & 0 & 0 & 2 & 1 & 0.816 \\
\hline 5 & 1 & -1 & 0 & 0 & 0 & 0 & 0 & 0 & 0 & 0 & 0 & 1 & 1 & 0.707 \\
\hline 6 & 0 & 0 & 0 & 1 & -1 & -1 & 0 & 0 & 0 & 0 & 0 & 1 & 2 & 0.816 \\
\hline 7 & 0 & 0 & 0 & 0 & 1 & -1 & 0 & 0 & 0 & 0 & 0 & 1 & 1 & 0.707 \\
\hline 8 & 0 & 0 & 0 & 0 & 0 & 0 & 0 & 1 & 1 & -1 & -1 & 2 & 2 & 1.000 \\
\hline 9 & 0 & 0 & 0 & 0 & 0 & 0 & 0 & 1 & -1 & 0 & 0 & 1 & 1 & 0.707 \\
\hline 10 & 0 & 0 & 0 & 0 & 0 & 0 & 0 & 0 & 0 & 1 & -1 & 1 & 1 & 0.707 \\
\hline
\end{tabular}

$r=$ number of positive signs; $s=$ number of negative signs.
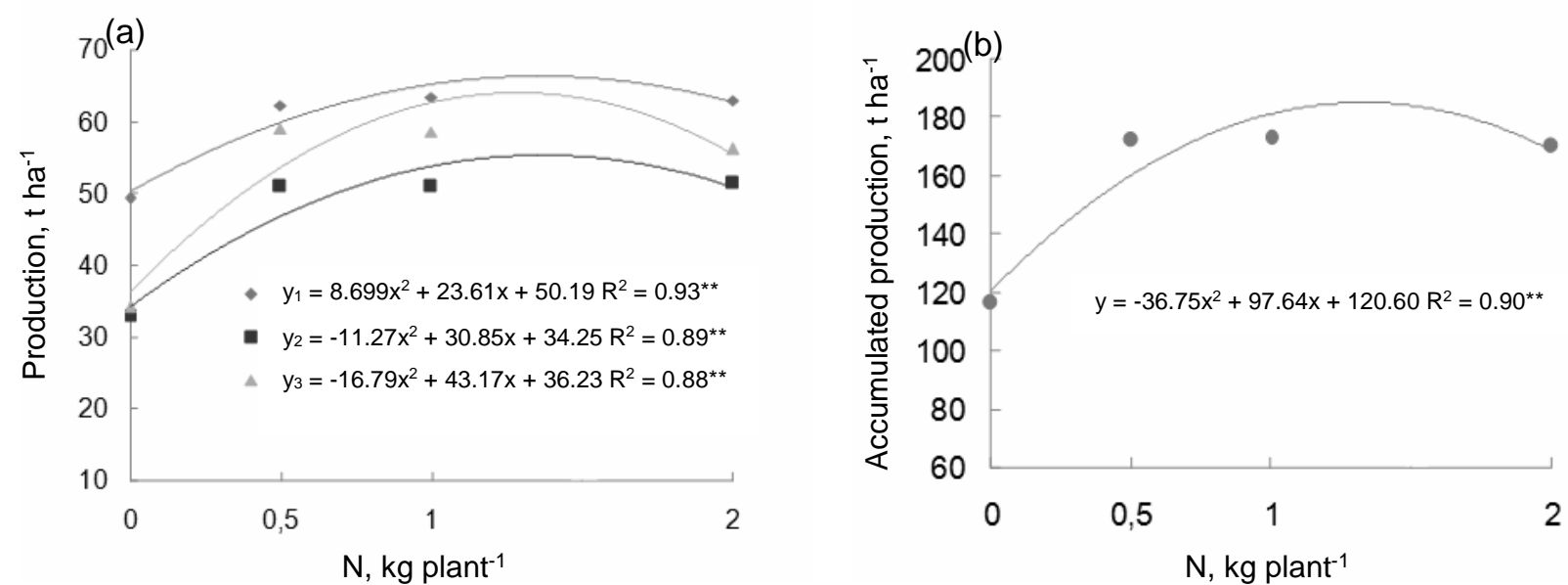

Figure 5 - Effects of $\mathrm{N}$ fertilization on yield per cycle (a) and accumulated production (b). $\mathrm{y}_{1}, \mathrm{y}_{2}$ and $\mathrm{y}_{3}$ represent the first, second and third production cycles; respectively.Table 3. Productive cycle influenced the productivity of 'Paluma' guava trees. 
Table 3 - Productive cycle effect on 'Paluma' guava trees yield.

\begin{tabular}{lcccc}
\hline \multirow{2}{*}{ Cycle } & \multicolumn{2}{c}{ Production } & Average fruit weight & Number of fruits \\
& $\left(\mathrm{kg} \mathrm{plant}^{-1}\right)$ & $\left(\mathrm{t} \mathrm{ha}^{-1}\right)$ & $(\mathrm{g})$ & $\left(\right.$ fruit plant $\left.^{-1}\right)$ \\
\hline Fall/Spring & $207.8 \mathrm{C}$ & $59.4 \mathrm{C}$ & $116.8 \mathrm{a}$ & $1,790 \mathrm{~b}$ \\
Summer/Winter & $162.4 \mathrm{a}$ & $46.5 \mathrm{a}$ & $147.2 \mathrm{~b}$ & $1,108 \mathrm{a}$ \\
Spring/Fall & $181.7 \mathrm{~b}$ & $52.0 \mathrm{~b}$ & $167.6 \mathrm{C}$ & $1,085 \mathrm{a}$ \\
\hline
\end{tabular}

Means followed by the same letters do not statistically differ by Tukey test at $5 \%$ probability; ${ }^{1},{ }^{2}$ and ${ }^{3}-$ first, second and third cycles, respectively.

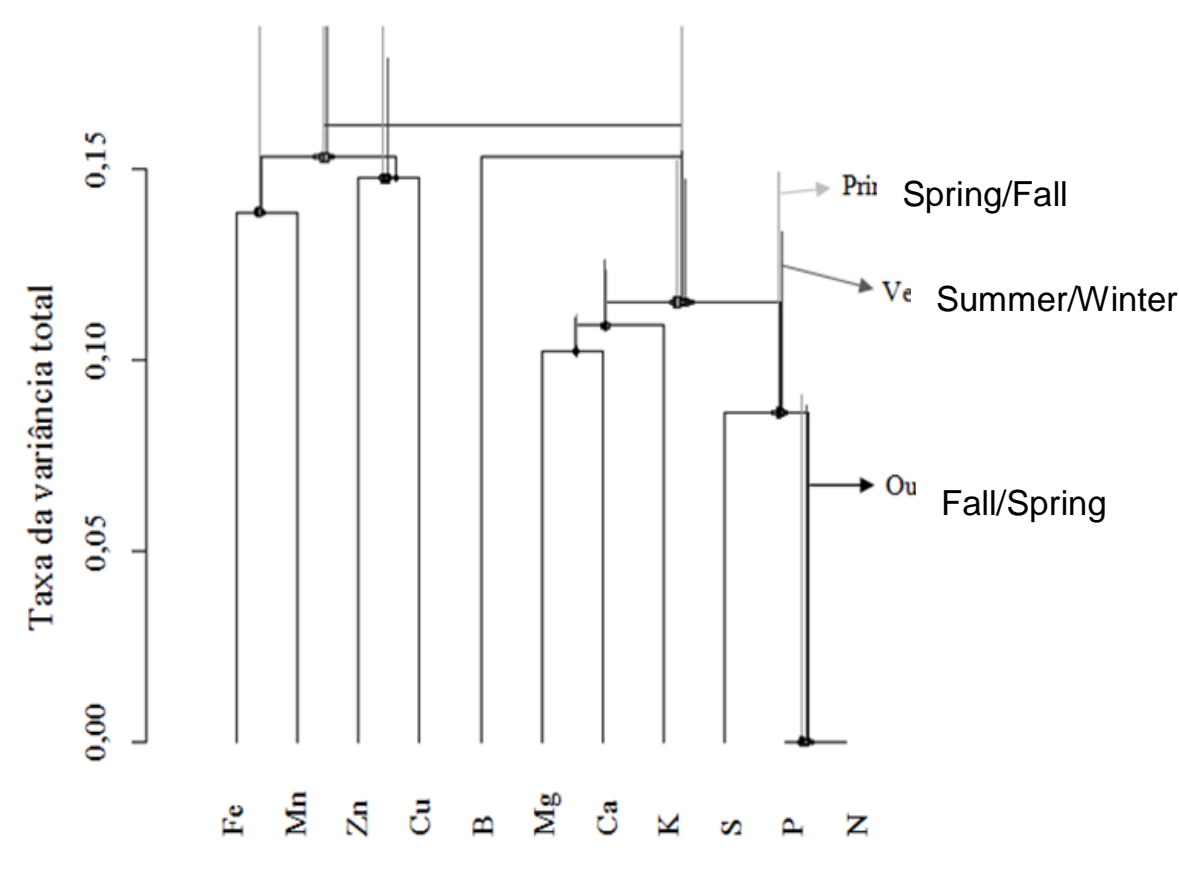

Figure 6 - Nutrient balance dendrogram representing the sequential binary partition between nutrients in buckets.

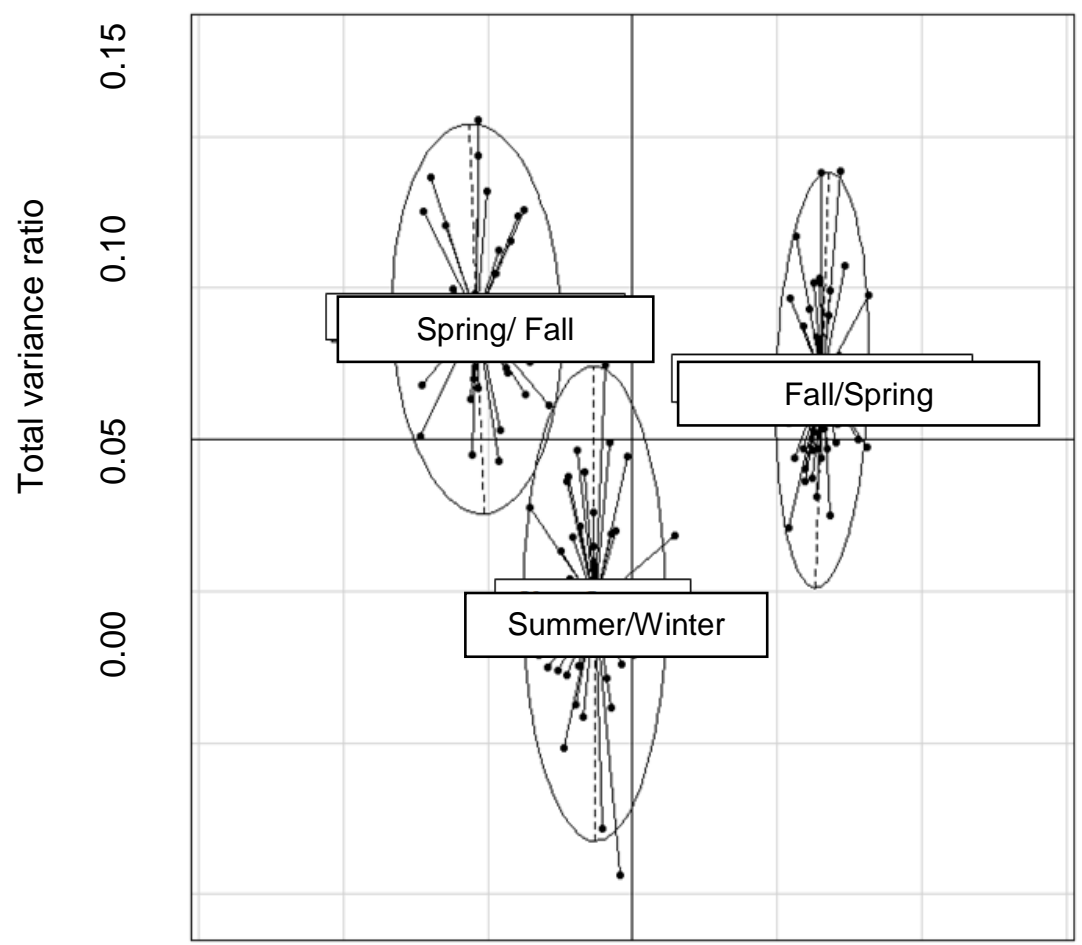

Figure 7 - Discriminant analysis of nutrients for culture cycle of 'Paluma' guava trees. 


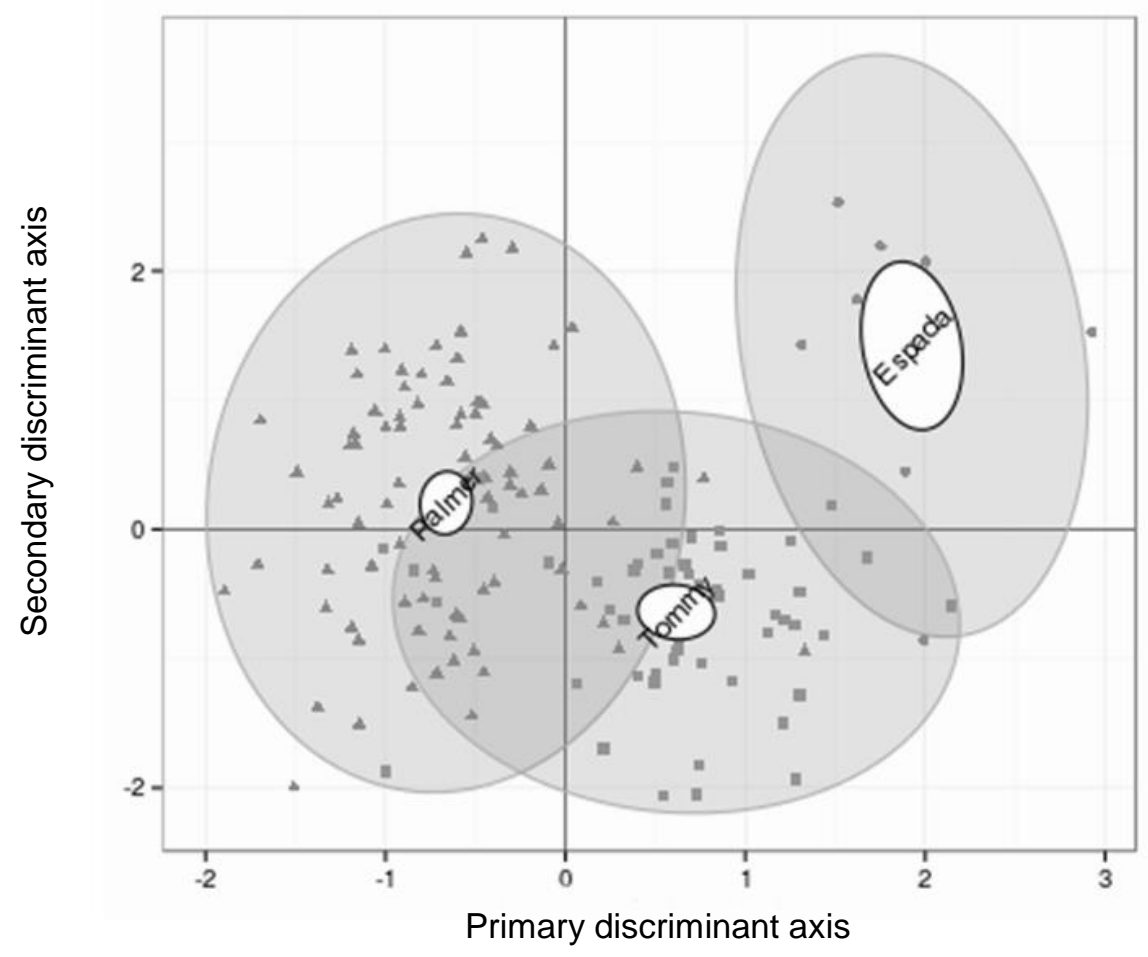

Figure 8 - Discriminant analysis of mango cultivars in São Paulo state, Brazil.

\section{References}

Aitchison J (1986) The statistical analysis of compositional data. Chapman \& Hall. 416p.

Aitchison, J. \& Greenacre, M. (2002). Biplots of compositional data. Applied Statistics 51, 375-392.

Amorim DA, Souza HA, Rozane DE, Montes RM, Natale W (2015) Adubação nitrogenada e potássica em goiabeiras 'Paluma': II. Efeitos no estado nutricional das plantas. Revista Brasileira de Fruticultura 37(1): 210-219.

Bataglia OC (2005) Métodos diagnósticos da nutrição potássica com ênfase no DRIS. In: Yamada T, Roberts TL (eds.). Potássio na agricultura brasileira. Potafos, p.321-341.

Bataglia OC, Dechen AR, Santos WR (1996) Princípios da diagnose foliar. In: Alvarez VHV, Fontes LEF, Fontes MPF (eds.) O solo nos grandes domínios morfoclimáticos do Brasil e o desenvolvimento sustentado. SBCS-UFV, p.647660.

Bataglia OC, Santos WR (1990) Efeito do procedimento de cálculo e da população de referência nos índices do sistema integrado de diagnose e recomendação (DRIS). Revista Brasileira de Ciência do Solo 14(1): 339-344.

Beaufils ER (1973) Diagnosis and recommendation integrated system (DRIS). University of Natal. 132p. (Soil Science Bulletin, 1).
Beverly RB (1987) Comparison of DRIS and alternative nutrient diagnostic methods for soybean. Journal of Plant Nutrition 10(8): 901-920.

Beverly RB (1993) DRIS Diagnoses of soybean nitrogen, phosphorus, and potassium status are unsatisfactory. Journal of Plant Nutrition 16(8):1431-1447.

Bhargava BS, Chadha KL (1988) Leaf nutrient guide for fruit and plantation crops. Fertilizer News 33(7): 21-29.

Chayes, F. (1960) On correlation between variables of constant sum. Journal of Geophysical Research, 65: 4185-4193.

Egozcue JJ, Pawlowsky-Glahn V (2005) Groups of parts and their balances in compositional data analysis. Mathematical Geology 37(7): 795-828.

Egozcue JJ, Pawlowsky-Glahn V, Mateu-Figueras G, Barceló-Vidal C (2003) Isometric log-ratio transformations for compositional data analysis. Mathematical Geology 35(3):279-300.

Elwali AMO, Gascho GJ (1984) Soil testing, foliar analysis, and DRIS as guide for sugarcane fertilization. Agronomy Journal, 76:466-470.

Epstein E, Bloom AJ (2006) Nutrição mineral de plantas, princípios e perspectivas. Planta. 86p.

Holland DA (1966) The interpretation of leaf analysis. Journal of Horticultural Science. 41:311-329. 
Hoogerheide HC (2005) DRIS para avaliação do estado nutricional da soja em duas regiões do cerrado brasileiro. ESALQ-USP (Dissertação de Mestrado em Solos e Nutrição de Plantas). 94p.

Lagatu $\mathrm{H}$, Maume L (1934a) Le diagsontic foliaire de la pomme de terre. Annual Ecole Nationale Superieure Agronomique de Montpellier 22:50-158.

Lagatu H, Maume L (1934b) Recherches sur lê diagnostic foliaire. Annual Ecole Nationale Superieure Agronomique de Montpellier 22:257306.

Leite RA (1993) Avaliação do estado nutricional do cafeeiro conilon no estado do Espirito Santo utilizando diferentes métodos de interpretação de análise foliar. UFV (Tese de Doutorado em Solos e Nutrição de Plantas). 87p.

Letzsch WS, Sumner ME (1984) Effect of population size and yield level in selection of Diagnosis and Recommendation Integrated System (DRIS) norms. Communications in Soil Science and Plant Analysis 15:997-1006.

Lovell D, Müller W, Tayler J, Zwart A, Helliwell C. (2011) Proportions, percentages, ppm: do the molecular biosciences treat compoitional data right? In: Pawlowsky-Glahn V, Buccianti A (eds.) Compositional data analysis: Theory and Applications. NY: John Wiley and Sons. p. 193207.

Malavolta E (2006) Manual de nutrição mineral de plantas. Ceres. 638p.

Marschner H (1995) Mineral nutrition of higher plants. Academic Press. 674 pp.

Mourão Filho FAA (2000) DRIS em laranjeira 'Valência' sobre três porta-enxertos. ESALQ/USP (Tese de Livre-Docência). 105p.

Natale W, Rozane DE, Prado RM, Romualdo LM, Souza HA, Hernandes A (2011) Dose econômica de calcário na produtividade de caramboleiras. Revista Brasileira de Fruticultura 33(4):1294-1299.

Parent, LE (2011) Diagnosis of the nutrient compositional space of fruit crops. Revista Brasileira Fruticultura, 33: 321-334.

Parent LE, Natale W, Ziadi N (2009) Compositional nutrient diagnosis of corn using the Mahalanobis distance as nutrient imbalance index. Canadian Journal of Soil Science 89(4):383-390.

Parent LE, Dafir M (1992) A Theoretical Concept of Compositional Nutrient Diagnosis. Journal of the American Society for Horticultural Science 117(2):239-242.
Parent LE, Khiari L (2003) The compositional nutrient diagnosis of onions. Acta Horticulturae 627: 251-258.

Parent LE, Cambouris AN, Muhawenimana A (1994a) Multivariate diagnosis of nutrient imbalance in potato crops. Soil Science Society of America Journal 58:1432-1438

Parent LE, Isfan D, Temblay N, Karam, A (1994b) Multivariate compositional diagnosis of carrot crops. Journal of the American Society for Horticultural Science 119(3):420-426.

Parent LE, Khiari L, Pettigrew A (2005) Nitrogen diagnosis of Christmas needle greenness. Canadian Journal of Soil Science 85(4):939-947.

Parent LE, Poirier M, Asselin M (1995) Multinutrient diagnosis of nitrogen in plants. Journal of Plant Nutrition 18(5):1013-1025.

Parent SE, Parent LE, Egozcue JJ, Rozane DE, Hernandes A, Lapointe L, Gentile VH, Naess K, Marchand S, Lafond J, Mattos Junior D, Barlow P, Natale W (2013a) The plant ionome revisited by the nutrient balance concept. Frontiers in Plant Science 4:(article 39) 1-10.

Parent SE, Parent LE, Rozane DE, Hernandes A, Natale W (2012) Nutrient balance as paradigm of plant and soil chemometrics. In: ISSAKA RN (ed.) Soil Fertility, InTech Journals. p.83-114.

Parent SE, Parent LE, Rozane DE, Natale W (2013b) Plant ionome diagnosis using sound balances: case study with mango (Mangifera Indica). Frontiers in Plant Science 4:(article 449)112.

Pearson, K. (1897) Mathematical contributions to the theory of evolution. On a form of spurious correlation which may arise when indices are used in the measurement of organs. Proceedings of the Royal Society, 60: 489-502.

Prevot P, Ollagnier M (1957) Méthodes d'utilisation di diagnostic foliare. In: Analyse des plantes et problème des fumures minerals (IRHO), Paris, 1957, p.177-192.

Rozane DE, Natale W, Parent LE, Santos EMH (2012) The CND-Goiaba 1.0 software for nutritional diagnosis of guava (Psidium guajava), Paluma cultivar, in Brazil. Acta Horticulturae 959:161-166.

Sierra AP, Marchetti ME, Vitorino ACT, Novelino JO, Camacho MA (2010) Desenvolvimento de normas DRIS e CND e avaliação do estado nutricional da cultura do algodoeiro. Revista Brasileira de Ciência do Solo 34(1):97-104. 
Silva GGC, Neves JCL, Alvarez VVH, Leite FP (2005) Avaliação da universalidade das normas DRIS, M-DRIS e CND. Revista Brasileira de Ciência do Solo 29(5):755-761

Silva GGC, Neves JCL, Alvarez VVH, Leite FP (2004) Nutritional diagnosis for eucalypt by DRIS, M-DRIS, and CND. Scientia Agricola 61(5):507515.

Smith PF (1962) Mineral analysis of plant tissues. Annual Review of Plant Physiology 13:81-108.

Tanner, J. (1949) Fallacy of per-weight and persurface area standards, and their relation to spurious correlation. Journal of Physiology, 2: 1-15.

Ulrich A, Hills FJ (1967) Principles and practices of plant analysis. In: Hardy GW (ed.) Soil testing and plant analysis. Soil Science Society of America p.11-24. (Special Publication, 2).
Urano EOM, Kurihara $\mathrm{CH}$, Maeda S, Vitorino ACT, Gonçalves MC, Marchetti ME (2006) Avaliação do estado nutricional da soja. Pesquisa Agropecuária Brasileira 41(9):1421-1428.

Urano EOM, Kurihara CH, Maeda S, Vitorino ACT, Gonçalves MC, Marchetti ME (2007) Determinação de teores ótimos de nutrientes em soja pelos métodos chance matemática, sistema integrado de diagnose e recomendação e diagnose da composição nutricional. Revista Brasileira de Ciência do Solo 31(1):63-72, 2007.

Walworth JL, Sumner ME (1987) The Diagnosis and Recommendation Integrated System (DRIS). In: Stewart BA (ed.) Advances in Soil Science. p.149-188. 